\section{DET FELLES ER AT BREDE LYST!}

Ole Thomsen: Komediens kraft en bog om en genre. Akademisk Forlag 1986. 446 s. $350 \mathrm{kr}$.

Søren Kierkegaard skriver et sted, at der er bøger, som fortjener at påagtes, fordi de har, hvad man anpriser som en hæderlig egenskab ved vin: den har bouquet, den har en fortræffelig afpropning fra oldtiden eller middelalderen, og idet man åbner den, strømmer en så krydret, liflig og ejendommelig duft en imøde, at man bliver ganske besynderlig tilmode. En sådan situation kommer man i, når man åbner Ole Thomsens doktorafhandling Komediens kraft (forsvaret 27.3.1987 på Århus Universitet). Og som med den gode vin er etiketten her heller ikke særlig ophidsende.

Lad os begynde med et par impulsive og sporadiske kommentarer til Ole Thomsens afhandling.

Alene den begejstring og den glæde der skinner igennem, nủl de "rigtige" ord findes, gør bogen tillokkende. Et par eksempler: "...det silkeknitrende ord fisselette (..katapýgōn)" (s.15); "den skidne punker Diogenes..." (s.70); "..en metafor, hvori spermaen dunker på" (s.75). Og i forlængelse heraf: Latrinær komik som natpotte og et ord som skaldethed har fået sit eget opslag i det 30 siders omfattende og uundværlige navne- og emneindeks.

Hvad Ole Thomsen kan få ud af en ligning som slå $=æ d e=$ kneppe er fascinerende, hvor Plautus, Freud, Kleist og Molière vælter rundt imellem hinanden. F.eks. udlægges ligningen som tre lag, hvori komedien trækker filosoffen ned: kroppens smerte, ernæring og den kødelige kærlighed i et spring fra Plautus til Holberg (s.86-87).

Der kræves også aktiv poseren af læseren: "som jeg skrev, bryder mønstrene igennem så snart man går ud på gulvet - og spillet viser sig. Vil De ikke godt prøve? Og forpustet forstå, at tempo er noget i teksten, og ikke kun i instruktørers fantasi" (s.246). Dét er vist noget nyt i en disputats.

$*$

Allerede fra de første sider skinner det igennem, at det ikke er komediens historie, men komediens kraft, der er på dagordenen. Alligevel begyndes der på fornuftig vis med en vurdering af komediens opkomst og med en af komediegenrens største digtere: Aristofanes.

Aristofanes' projekt var at etablere livslyst i staten. Ole Thomsen beskriver hvordan hyldest og hån er polariteten i hans værk, og at det svarer til fallosritualets dobbelte rytme af indoptagelse og udstødelse. Ja, måske er dette begrebspar nøglen til selve komedien. Vi får se.

Imidlertid er det ikke her hensigten at redegøre for Aristofanes' komedier, det skal blot påpeges, at for Ole Thomsen finder de to største omvæltninger i komediens historie sted omkring $400 \mathrm{f} . \mathrm{Kr}$. og omkring 1800 efter. Ved den første tabes Aristofanes (delvis), ved den sidste genvindes han (delvis). Imellem ligger nea-trationen, den klassiske komedie.

På kryds og tværs foretages der generaliserende udsagn orn komedien. Lange historiske perioder beskrives på få linjer, eller der foretages bevidst koblinger mellem historisk uhomogeniserede personer som Freud, Oscar Wilde og Aristofanes. Men der er aldrig, som ofte i den uhomogeniserede mælk, tale om, at der er klumper $i$ teksten. Formålet er klart. Hvad der nok hænger sammen med Ole Thomsens overbevisning, at komediens genstand skifter med tiderne og sæderne, hvorimod dens 
form er evig. Derfor kan han på trods af epokeinddelinger trække en tråd fra Aristofanes til renæssancen og videre frem til Molière, Boileau, Holberg m.fl.

Det er ikke kun komedien, men også "modsætningen" tragedien og "mellempositionen" tragikomedien og satyrspillet, der inddrages, samt farcen og sågar vaudevillen og mimen.

Selv om intentionen ikike er en eksplicit inddragelse af det rociale og politiske, er afhandlirıen sprængfyldt med den slags. Især skal fremhæves et afsnit, hvori der foretages en politisk-ideologisk analyse af komedien under overskriften "Den kolde krig mellem satire og humor" (s.300-314). Satiren knytter an til aktuel socialkritik, mens humoren knytter an til almengyldig livskritik. Hér står sagen - lyder det: Satire i øst, humor i vest. Men som sædvanlig er det mere røget, end det er speget. Måske er svaret for vest: Det komiske drama overlader det til tilskueren selv at fælde dommen. Det er den bedste kunst; men mon det ikke også er den bedste politik (s.313). Vel vidende, at det både er forkert og kun er en af mange begrundelser, kan det siges, at den objektive grund til komedie er, at verden nu er kaotisk; hvorimod tragedien forudsætter en formet verden og skyld, nød, mådehold, overblik og ansvar, mens der i vort århundredes pølsefabrik hverken findes skyldige eller ansvarlige (s.310). Derfor komedie.

Ole Thomsen siger et sted, at for en bog om komisk drama fremstår ironi ikke som en kategori ved siden af en række andre, men som den frugtbare hovedkategori (s.45). Af den grund gøres der meget ud af at bestemme og beskrive ironiens agens. Og det pointeres, at selv om definitionen pà ironi er at sige det modsatte af, hvad man mener, og ironikeren således kan besternmes som tvesynet og distancerende, så er det forkert at tro, at ironikerens rollespil kun er en flugt, det kan som latteren generelt også være en fødselshjælper.

$$
*
$$

$\mathrm{Nu}$ til de egentlige teorier om komedien, der må formodes at være afhandlingens væsenskendetegn. Men som i denne anmeldelse skal man langt ind $i$ teksten for at komme frem til teorierne om komedien. Først efter et par hundrede siders omgang med komedien, der rejser et væld af spørgsmål, præsenteres Platon og Aristoteles som det komiskes grundlæggere i teorien (s.173). Nu bliver det til komik-teori for alvor!

Det skal indkredses, hvordan Aristoteles definerer komedien (fra s.160ff.). Det bliver hurtigt klart, at det komiske (komediens virkefelt er det komiske, på græsk: det latterlige) eller det latterlige er en del af det grimme, men noget grimt uden smerte, det grimme forstået som en form for underlødighed. Men idet tragedien kobles til - og problemstillingen differentieres under inddragelse af diverse andre teorier (Cicero, Kant m.fl.) og en mængde fortolkninger - bliver det nærmest umuligt at få præcist rede på Aristoteles' opfattelse.

Et sted lyder det med Aristoteles, at vittigheden (ingen græker skelner mellem det komiske og det vittige) bliver til ved snyd, den opbygger en forventning, som den ikke indfrier, man tager fejl, gennemskuer og glæder sig over ny indsigt. Herefter citeres Kant for at sige det samme: "Latteren er en affekt ud af den pludselige forvandling, af en spændt forventning til ingenting" (Kritik der Urteilskraft § 54). Tilsyneladende ren Aristoteles. Men så falder bomben, for hos Kant er erkendelsen undgået: "hvilken forskel er vigtig, ja, måske ér det rigtigt at forstå 
Kants nichts som NICHTS .. Kant som Højholts forbereder, Kant post-modernismens far" (s.163-164); et spor Ole Thomsen forfølger videre.

Men hvad er egentlig en komedie, ud over at det komiske bliver til komedie? Afgørende er det, at komedien altid stiller misforholdet til skue. Derfor har kærligheden altid været et flittigt emne, for her ses misforholdet mellem ord og gerning, teori og praksis, redebon ånd og skrøbeligt kød (s.191).

I komedien aktualiseres ordenes ekstra betydningspotentiale, ja Ole Thomsen definerer komedie som en kontekst til bestandig, uventet aktualisering af medbetydninger. Denne produktion, gennem forskydninger, af ekstrabetydning, er uventet, idet den enten sker uden om den talendes bevidsthed, da denne mener sig $i$ besiddelse af en ren, saglig diskurs, i hvilken tilhøreren să interpolerer medbetydninger, eller den foretages netop af den talende, $i$ et omfang som overgår tilhørerens fantasi. Begge dele er komiske, i det første tilfælde transporteres der underbevidsthed til den talende, $i$ det andet tilfælde fra den talende til tilhøreren (s.86).

Som det kan ses, har Ole Thomsen i sin beskrivelse af komedien et godt øje til psykoanalysen, og et af højdepunkterne i afhandlingen er da også et afsnit om Freud. Det er at finde i slutspurten og implicerer en gennemgang af Freuds teori om vitsen, der med de tre begreber vittigheden, det komiske og humoren repulserende fører læseren tilbage i teksten.

Kritisk skal det păpeges, at indforstăetheden nogle steder og specielt i forbindelse med omtalen af Aristofanes' komedier er enorm, men samtidig benyttes der som allerede antydet over alt et forløsende sprog, der forførisk gør, at man sidder tilbage med en fornemmelse af, at indforståetheden ikke betyder noget. Uden at være sikker på noget bestemt sidder man tillige efter endt læsning tilbage med en følelse af at have været omkring samtlige komedier i vor kulturs historie.

Et sted har Ole Thomsen en kommentar til Northrop Frye's komedieteori, hvor der loves for meget, hvor man med spænding slår op på note 321 , hvortil der henvises, hvis man vil finde ud af, hvorfor Ole Thomsen ikke for komediens vedkommende er Frye-discipel. Men desværre står der hverken her eller andetsteds noget derom.

Som det kan ses, har denne kommentar knyttet mere an til diverse filosofiske og idéhistoriske "mellemspil", hvor problematikkerne indkredses, end til analysen af komedierne, som undervejs i afhandlingen er mangfoldige og komplekse. Faktisk har der i det foregående slet ikke været nævnt en eneste af de kornedier, som det trods alt har været Ole Thomsens hovedærinde at beskæftige sig med: Aristofanes', Molière's, Shakespeare's, Holberg's, Hei-berg's etc. Men sådan skal det åbenbart være.

Bonjour, la Nuit

Ole Morsing 